\title{
Production, Optimization, and Characterization of an Acid Protease from a Filamentous Fungus by Solid-State Fermentation
}

\author{
Abdilbar Usman, Said Mohammed, and Jermen Mamo \\ Department of Biology, College of Natural and Computational Science, Debre Berhan University, Debre Berhan, Ethiopia \\ Correspondence should be addressed to Jermen Mamo; jermenmamo@yahoo.com
}

Received 19 December 2020; Revised 12 March 2021; Accepted 7 April 2021; Published 29 April 2021

Academic Editor: Diriba Muleta; dmuleta@gmail.com

Copyright (C) 2021 Abdilbar Usman et al. This is an open access article distributed under the Creative Commons Attribution License, which permits unrestricted use, distribution, and reproduction in any medium, provided the original work is properly cited.

\begin{abstract}
Acid proteases represent an important group of enzymes, extensively used in food and beverage industries. There is an increased demand for acid proteases adapting to the industrial extreme environment, especially lower $\mathrm{pH}$. Thus, this necessitates the search for a better acid protease from fungi that best performs in industrial conditions. The fungal isolates were isolated from grape and dairy farm soil using potato dextrose agar and further screened for protease production based on the hydrolysis of clear zone on skim milk agar. The potential fungi were then subjected to secondary screening under solid-state fermentation (SSF). After the secondary screening, the potential fungus was identified to the genus level by the macroscopic and microscopic methods. The growth conditions and media composition for the potential fungus were further optimized under SSF. The crude enzyme produced by the potential isolate was characterized after partial purification by acetone and ammonium sulfate precipitation. A total of 9 fungal isolates showed protease production in primary and secondary screening; however, one potential isolate (Z1BL1) was selected for further study based on its protease activity. The isolate was identified to the genus Aspergillus based on their morphological features. The maximum acid protease from the isolate Z1BL1 was obtained using fermentation media containing wheat bran as a solid substrate, $1 \mathrm{~mL}$ of $3.2 \times 10^{6}$ inoculum size, $50 \%$ moisture content, and pH 4.5 upon 120 -h incubation at $30^{\circ} \mathrm{C}$. The acetone-precipitated enzyme exhibited the maximum activity at $50^{\circ} \mathrm{C}$ and $\mathrm{pH} 5$ with stability at $\mathrm{pH} 4-6$ and temperature $40-60^{\circ} \mathrm{C}$. Thus, the acid protease produced from Aspergillus showed suitable enzyme characteristics required in the industry and could be a candidate for application in the food industry after further purification.
\end{abstract}

\section{Introduction}

Proteases are the most essential group of enzymes from biotechnological perspectives, and they catalyze the hydrolysis of peptide bonds $[1,2]$. Proteases account for about $65 \%$ of the total worldwide enzyme sales, and they are made up of a complex group of enzymes and differ in some of their properties such as substrate specificity, catalytic mechanism, temperature, and $\mathrm{pH}$ optima and stability profile [2].

Aspartic proteases (EC 3.4.23), also known as acidic proteases, are a subfamily of endopeptidases that have been isolated from diverse sources, including viruses, bacteria, fungi, plants, and animals [1]. Several fungal aspartic proteases have been purified and characterized as rennin-like and pepsin-like enzymes [3]. The rennin-like enzymes are produced by Endothia parasitica (endothiapepsin, EC
3.4.23.22), Mucor, and Rhizomucor species (mucorpepsin, EC 3.4.23.23). The pepsin-like enzymes include aspergillopepsin (aspergillopepsin I, EC 3.4.23.18) from Aspergillus species [4] and rhizopuspepsin (EC 3.4.23.21) from Rhizopus species [1].

Most of the aspartic proteases (Aps) show the best activity at low $\mathrm{pH}$ ( $\mathrm{pH} 3$ to 4 ) and have isoelectric points in the $\mathrm{pH}$ range of 3 to 4.5 [5]. They are inhibited by a hexapeptide from Streptomyces that contains two statin residues called pepstatin. Aspartic proteases are also sensitive to diazoacetyl-DL-norleucine methyl ester (DAN) and 1, 2-epoxy3 -(p-nitrophenoxy) propane (EPNP) in the presence of copper ions. Microbial acid proteases exhibit specificity against aromatic or bulky amino acid residues on both sides of the peptide bond, which is similar to pepsin, but their action is less stringent than that of pepsin [5]. 
Acid proteases have a wide range of applications in various industries such as food industry, beverage industry, and pharmaceutical industry [5]. The increasing importance of these enzymes and their numerous applications in different industries improves the effort to investigate acid protease with enhanced activity from fungi. The shortage of plant and animal proteases to meet the present world demands of industrial enzymes has directed an increased interest in microbial proteases $[5,6]$. The diverse ecological niche in Ethiopia and the presence of very few reports on fungal acid proteases from Ethiopia [7] necessitate the search for potential fungal isolates with improved acid protease activity. Therefore, the present study was intended to isolate and screen fungi from soil samples for the production, optimization, and characterization of acid protease.

\section{Materials and Methods}

2.1. Description of Study Area. A total of 21 soil samples were collected from dairy and grape farms in three regional states of Ethiopia, i.e, Amhara Region (Shewa Robit); Oromia Region (Ziway); and Southern Nations, Nationalities, People's Region (Halaba). Shewa Robit is located at $10006^{\prime}$ $650^{\prime \prime}-09057^{\prime} 957^{\prime \prime} \mathrm{N}, 039054^{\prime} 37^{\prime \prime}-039056^{\prime} 579^{\prime \prime} \mathrm{E}$, in North Shewa Zone of the Amhara regional state, $225 \mathrm{~km}$ north of Addis Ababa, Ethiopia. It is a low-land (submoist warm) area with altitudes ranging between 1120 and $1350 \mathrm{~m}$ above sea level. The climate data of the study area recorded for the last ten years show an average annual maximum and minimum temperature and precipitation of 32.1 and $16.1^{\circ} \mathrm{C}$ and $968 \mathrm{~mm}$, respectively. The most dominant soil type in Shewa Robit is vertisols, which have clay texture with a clay content of $56 \%$ and $10 \%$, silt $34 \%$, and a $\mathrm{pH}$ value of 8.02 [8].

The second study area Ziway is located at $7.58^{\circ} \mathrm{N}$ latitude and $38.43^{\circ} \mathrm{E}$ longitude in the southern part of the Oromia regional state situated in the Mid Rift Valley, $160 \mathrm{~km}$ south of Addis Ababa. It is categorized under the semiarid, with a minimum mean temperature of $12.7^{\circ} \mathrm{C}$ and a maximum mean temperature of $27.2^{\circ} \mathrm{C}$ with a relative humidity of $60 \%$. The area has an altitude ranging between 1500 and 2000 meters above sea level. The average annual rainfall ranges from 650 to $750 \mathrm{~mm}$, and the distribution is highly variable between and within years. Vertisol is the predominant soil type with sand-silt-clay in the portion of $33: 48: 18$, respectively, and has a $\mathrm{pH}$ of 7.88 [9].

Halaba special district is located in Southern Nation, Nationalities and Peoples Region (SNNPR), at the distance of $85 \mathrm{~km}$ from Hawassa town and $310 \mathrm{~km}$ from Addis Ababa, the capital city of Ethiopia (Figure 1). The study site is found within an altitude ranging from 1554 to $2149 \mathrm{~m}$ above sea level, and an astronomic location of $38^{\circ} 7^{\prime} 0^{\prime \prime} \mathrm{E}$ longitude and $7^{\circ} 18^{\prime} 0^{\prime \prime} \mathrm{N}$ latitude. Halaba special district is generally characterized by dry climatic condition with about $86 \%$ mid-land (Weinadega) and 14\% law-land (Kola) zones. The mean annual rainfall of the study area is ranging from 857 to 1085 $\mathrm{mm}$, while the mean annual temperature varies from 17 to $20^{\circ} \mathrm{C}$ with a mean value of $18^{\circ} \mathrm{C}[10]$.

2.2. Sample Collection. Five hundred grams of soil $(5-10 \mathrm{~cm}$ below the surface) was collected aseptically from the grape farm and dairy farm areas located at Showa Robit, Ziway, and Halaba,
Ethiopia, in September 2019. Soil samples were sieved (3-4 mm mesh), homogenized, and stored at $4^{\circ} \mathrm{C}$ at the Microbiology Laboratory of the Biology Department, Debre Berhan University, for further use as the protocol described by Li et al. [11].

2.3. Isolation of Fungi. The fungi were isolated by serial dilution technique as described by Oyeleke et al. [12]. Thus, ten grams of each soil sample was mixed with $90 \mathrm{~mL}$ of distilled water and homogenized by agitation for $20 \mathrm{~min}$. They were prepared to appropriate dilutions from which $0.1 \mathrm{~mL}$ of each sample suspension was plated on potato dextrose agar (PDA) (Microgen, India) plates containing $(0.05 \mathrm{~g} / \mathrm{L})$ chloramphenicol. The plates were incubated at $30^{\circ} \mathrm{C}$ for 5-7 days to isolate distinctive colonies. Each colony was then restreaked on the same medium to purity and preserved at $4^{\circ} \mathrm{C}$.

\subsection{Primary Screening for Protease-Producing Fungi.} Primary screening for protease production was tested using the skim milk agar (Nestle TM, Frankfurt, Germany) medium for the production of the clear zone [13]. The detection medium (Skim Milk Agar, SMA) was prepared using $20 \mathrm{~g}$ of skim milk, $20 \mathrm{~g}$ of agar-agar each dissolved in $200 \mathrm{~mL}$ distilled water, and $600 \mathrm{~mL}$ of $0.2 \mathrm{M}$ phosphate buffer $\left(\mathrm{K}_{2} \mathrm{HPO}_{4}\right.$ and $\mathrm{KH}_{2} \mathrm{PO}_{4}, \mathrm{pH}$ 5.0). All the three media components were autoclaved separately to avoid coagulation and charring of milk due to the presence of buffer salts and later mixed under sterile conditions. The plates were then subsequently inoculated with mycelia from 5-day-old culture and incubated at $30^{\circ} \mathrm{C}$ for 2 days. The plates were examined for the formation of the clearing zone by flooding them with a solution of $10 \%$ trichloroacetic acid (TCA) or $10 \%$ tannic acid. The relative enzyme activity was calculated using the following formula:

$$
\mathrm{REA}=\frac{\mathrm{CZD}}{\mathrm{CD}}
$$

where REA: relative enzyme activity, CZD: clear zone diameter, and CD: colony diameter $[13,14]$.

\subsection{Secondary Screening for Acid Protease under Solid-State Fermentation}

2.5.1. Inoculum Preparation. Fungal isolates were grown on PDA and incubated at $30^{\circ} \mathrm{C}$ for 5 days. They were scrapped using $10 \mathrm{~mL}$ of sterile distilled water to prepare spore suspension. $0.5 \mathrm{~mL}$ of spore solution $\left(10^{6}\right.$ spores $\left./ \mathrm{mL}\right)$ was used according to the study by Sathya et al. [15].

2.5.2. Medium and Cultural Conditions for Solid-State Fermentation for Fungi (M1). For solid-state fermentation, $0.5 \mathrm{~mL}$ of spore suspension $\left(10^{6}\right.$ spores $\left./ \mathrm{mL}\right)$ was transferred into $250 \mathrm{~mL}$ Erlenmeyer flasks containing wheat bran $(10 \mathrm{~g})$, skim milk powder $(2.0 \mathrm{~g})$, and $10 \mathrm{~mL}$ of salt solution $(\mathrm{g} / \mathrm{L}$ : 2.0, $\mathrm{KNO}_{3} ; 0.5, \quad \mathrm{MgSO}_{4} \cdot 7 \mathrm{H}_{2} \mathrm{O} ; 1.0, \quad \mathrm{~K}_{2} \mathrm{HPO}_{4} ; 0.439$, $\mathrm{ZnSO}_{4} \cdot 7 \mathrm{H}_{2} \mathrm{O} ; 1.116, \mathrm{FeSO}_{4} \cdot 7 \mathrm{H}_{2} \mathrm{O} ; 0.203, \mathrm{MnSO}_{4} \cdot 7 \mathrm{H}_{2} \mathrm{O}$, and $\mathrm{pH}$ 5) [15]. The flasks were incubated at $30^{\circ} \mathrm{C}$ for 6 days under static conditions. 
2.5.3. Medium and Cultural Conditions for Solid-State Fermentation for Fungi (M2). The solid-state substrate was also prepared in $250 \mathrm{~mL}$ Erlenmeyer flasks containing $10 \mathrm{~g}$ of wheat bran (Durum wheat bran) moistened by adding $12 \mathrm{~mL}$ of $\mathrm{HCl}(0.2 \mathrm{M})$ and mixed thoroughly. Then, the flasks were autoclaved at $121^{\circ} \mathrm{C}$ for $30 \mathrm{~min}$. Then, $0.5 \mathrm{~mL}$ of $\left(10^{6}\right.$ spores/ $\mathrm{mL}$ ) spore suspension was inoculated into SSF media and incubated at $30^{\circ} \mathrm{C}$ for 6 days [16].

2.6. Enzyme Extraction. The enzyme was extracted according to the method described by Silveira et al. [17]. Thus, the fermented substrates were dispersed in $100 \mathrm{~mL}$ of distilled water (1:10 ratio of Bran-solvent w/v) and vigorously shaken on a rotary shaker (MaxQ 2000 Open-Air Platform Shaker; ThermoFisher Scientific, USA) at $240 \mathrm{rpm}$ at room temperature for $40 \mathrm{~min}$ and filtered using a cotton cloth. The filtrate was then centrifuged (NF200, year 2009, $\mathrm{SN} 02-4005$, Turkey) at $10000 \mathrm{x} \mathrm{g}, 4^{\circ} \mathrm{C}$ for $10 \mathrm{~min}$. The supernatant was used as a crude enzyme.

2.7. Assay for Acid Protease Activity. Protease activity was determined using hemoglobin as a substrate [18]. Enzyme preparation $(0.5 \mathrm{~mL})$, suitably diluted, was mixed with $1 \mathrm{~mL}$ of $2 \%(\mathrm{w} / \mathrm{v})$ hemoglobin prepared in $100 \mathrm{mM}$ glycine $\mathrm{HCl}$ buffer ( $\mathrm{pH}$ 3.0), and the mixture was incubated in a water bath at $50^{\circ} \mathrm{C}$ for $10 \mathrm{~min}$. The reaction was terminated by adding $2 \mathrm{~mL}$ trichloroacetic acid 5\% (w/v). The mixture was allowed to stand at room temperature for $15 \mathrm{~min}$ and then centrifuged (NF200, year 2009, SN 02-4005, Turkey) at $10,000 \times \mathrm{g}$ for $15 \mathrm{~min}$ to remove the precipitate. The absorbance of the soluble fraction was measured at $280 \mathrm{~nm}$. A standard curve was generated using tyrosine solutions. One unit of protease activity was defined as the amount of enzyme required to liberate $1 \mu \mathrm{g}$ of tyrosine per min under the experimental conditions. The tyrosine standard curve and protease activity of the enzyme were calculated.

2.8. Tyrosine Standard Curve. The protease activity of the enzyme was determined using the tyrosine standard curve. The absorbance of standard tyrosine solution (tyrosine solutions at $0-250 \mu \mathrm{g} / \mathrm{mL})$ was measured at $280 \mathrm{~nm}$ (A280) using a spectrophotometer (UV-VIS, Liantrinsat, and Model-CF728YW-UK). Then, a standard curve was plotted using the $\mathrm{OD}$ reading and the tyrosine concentrations (Figure 1). The OD reading of the samples (assay conducted using fungal protease) was converted to the liberated amino acid (tyrosine) using the formula generated from the standard curve. Finally, the tyrosine liberated during the assay was converted to protease activity using the following formula:

$$
\operatorname{PA}\left(\frac{U}{m L}\right)=\frac{\mu \operatorname{Tyr} * V_{t}}{V_{s} * T * V_{a}},
$$

where PA: protease activity, $\mu$ Try: $\mu \mathrm{g}$ of tyrosine equivalent released, $V_{t}$ : total volume of the assay in $\mathrm{mL}, V_{s}$ : sample volume, $T$ : reaction time in minutes, and $V_{a}$ : volume of the assay used for absorbance measurement.

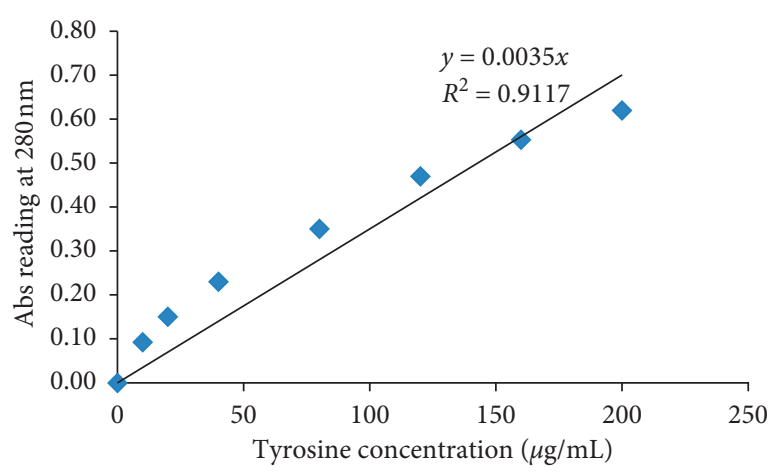

Figure 1: Tyrosine standard curve for acid protease activity.

2.9. Assay for Milk Clotting Activity. Milk clotting activity was determined according to the method of Arima et al. [19], which is based on the visual evaluation of the appearance of the first clotting flakes, and expressed in terms of Soxhlet units (SU). One Soxhlet unit is defined as the amount of enzyme that clots $1 \mathrm{~mL}$ of the substrate in $40 \mathrm{~min}$ at $35^{\circ} \mathrm{C}$. To perform the assay, $0.1 \mathrm{~mL}$ of the sample was added to a glass test tube containing $1 \mathrm{~mL}$ of reconstituted skim milk solution $(10 \mathrm{~g}$ skim milk powder dissolved in $100 \mathrm{~mL}$ of $0.01 \mathrm{M}$ $\mathrm{CaCl}_{2}$ solution) pre-incubated at $35^{\circ} \mathrm{C}$ for $10 \mathrm{~min}$. The mixture was mixed well, and the clotting time $t$ (s) was measured using a chronometer. The clotting activity was calculated using the following formula:

$$
\mathrm{SU}=\frac{(2400 \times 1 \times D)}{(0.1 \times t)},
$$

where $D$ is the dilution factor and $t$ is the clotting time in seconds.

2.10. Morphological Characterization. The cultural characteristics (colony growth rate, colony texture, colony color, colony size, and degree of sporulation) of the fungal isolates were studied by inoculating them on Czapek Dox agar (CDA), potato dextrose agar (PDA), and malt extract agar (MEA) as described by Zulkifli and Zakaria [20]. The microscopic structures of the isolates were observed under the microscope after having prepared them on a slide culture and identified to the genus level based on species descriptions $[21,22]$.

\subsection{Optimization of Cultural Conditions and Media Composition for the Production of Acid Protease under SSF}

2.11.1. Experimental Setup for Preliminary Screening for Production of Acid Protease in SSF. The experimental setup for solid-state fermentation was according to the study by Fernández-Lahore et al. [16] with slight modification. Two types of fermentation media were used for solid-state fermentation. The 1 st media contained $10 \mathrm{~g}$ of wheat bran (WB) and $2 \mathrm{~g}$ of skim milk powder moistened by $12 \mathrm{~mL} \mathrm{HCl}$ $(0.2 \mathrm{M})$. The 2 nd media contained $10 \mathrm{~g}$ of wheat bran (WB) and $2 \mathrm{~g}$ of skim milk powder moistened by $10 \mathrm{~mL}$ mineral solutions. The flasks were then incubated at $30^{\circ} \mathrm{C}$ for six days. 
2.11.2. Effect of Substrate on Acid Protease Production. Screening of the media composition for acid protease production was performed by a one-variable-at-a-time approach $[22,23]$. Thus, $0.5 \mathrm{~mL}$ of spore suspension $\left(10^{6}\right.$ spores $/ \mathrm{mL}$ ) from potential fungal isolates were inoculated into the flask containing 10 grams of each substrate (wheat bran, Rice Bran) in 250 Erlenmeyer flasks moistened by $12 \mathrm{~mL} \mathrm{HCl}(0.2 \mathrm{M}) /$ salt solution and incubated at $30^{\circ} \mathrm{C}$ for $144 \mathrm{~h}$. The crude enzyme was extracted as previously described and assayed for acid protease activity. After having tested the effect of substrates on enzyme production, the highest enzyme-producing substrate was selected and tested for further optimization.

2.11.3. Effect of Incubation Time. The effect of incubation time on acid protease production was studied by inoculating the flasks containing wheat bran, the best substrate, with $0.5 \mathrm{~mL}$ of spore suspension $\left(10^{6}\right.$ spores $\left./ \mathrm{mL}\right)$ and incubated at $30^{\circ} \mathrm{C}$ for different periods ranging from $24 \mathrm{~h}$ to $144 \mathrm{~h}$ [23]. The acid protease activity was determined as indicated in Section 2.7.

2.11.4. Effect of Incubation Temperature. The fungal spores inoculated into the SSF medium in $250 \mathrm{~mL}$ Erlenmeyer flasks were incubated at temperatures of $20^{\circ} \mathrm{C}, 25^{\circ} \mathrm{C}, 30^{\circ} \mathrm{C}$, $35^{\circ} \mathrm{C}, 40^{\circ} \mathrm{C}$, and $45^{\circ} \mathrm{C}$ for $120 \mathrm{~h}$ to determine the optimum temperature. Then, the obtained optimum temperature was used for further study [23].

2.11.5. Effect of Inoculum Size. The effect of inoculum size on acid protease production was studied by inoculating $0.2 \mathrm{~mL}, 0.5 \mathrm{~mL}, 1 \mathrm{~mL}, 1.5 \mathrm{~mL}$, and $2 \mathrm{~mL}$ of $\left(3.2 \times 10^{6}\right.$ spores/ $\mathrm{mL})$ spore suspension into SSF media. Then, the inoculated flasks were incubated at the optimum temperature for $120 \mathrm{~h}$ [23].

2.11.6. Effect of Moisture Content. The effect of initial moisture content for enzyme production was tested by moistening substrate with distilled water at different percentages of moisture content $45 \%, 50 \%, 55 \%, 60 \%, 65 \%$, and $70 \%$ to find out the best percentage for enzyme production [24].

2.11.7. Effect of Initial Media $p H$. The effect of initial media $\mathrm{pH}$ on acid protease production was optimized by adjusting the SSF medium to $\mathrm{pH} 2.0,2.5,3.0,3.5,4.0,4.5,5.0,5.5,6.0$, 6.5 , and 7.0 using $\mathrm{HCl}$ or diluted $\mathrm{NaOH}$ [23].

\subsection{Partial Purification}

2.12.1. Acetone Precipitation. The crude enzyme extract was precipitated with chilled acetone (acetone or $75 \%$ acetone). Two volumes of chilled acetone were slowly added to the extract, and the precipitate was allowed to settle for $1 \mathrm{~h}$ at $-18^{\circ} \mathrm{C}$ to permit complete precipitation. The precipitated proteins were then separated by centrifuging at $10000 \times \mathrm{g}$ and $4^{\circ} \mathrm{C}$ for $10 \mathrm{~min}$. The pellet was dried in the open air for $30 \mathrm{~min}$ to remove trace amounts of acetone and dissolved in $0.02 \mathrm{M}$ phosphate buffer, $\mathrm{pH} 6.0$ [26].

2.12.2. Ammonium Sulfate Precipitation. The crude enzyme extract was precipitated with ammonium sulfate according to the study by Nouani et al. [26]. Accordingly, $300 \mathrm{~mL}$ of the crude extract was added to $1200 \mathrm{~mL}$ saturated ammonium sulfate $(100 \%)$ to precipitate. Then, the enzymatic solution was decanted for one night at $4^{\circ} \mathrm{C}$ and centrifuged at $10000 \times \mathrm{g}$ for $10 \mathrm{~min}$ at $4^{\circ} \mathrm{C}$, and the pellet was suspended in the phosphate buffer (0.02 M; pH 6).

\subsection{Enzyme Characterization}

2.13.1. Determination of Optimum $\mathrm{pH}$ and Its Stability. The optimum $\mathrm{pH}$ of the enzyme preparation was studied over a $\mathrm{pH}$ range of $2.0-7.0$ at $50^{\circ} \mathrm{C}$ using $2 \%(\mathrm{w} / \mathrm{v})$ hemoglobin as described previously. For studying $\mathrm{pH}$ stability, the crude enzyme was incubated in buffers of different $\mathrm{pH}$ values in the range of $\mathrm{pH} 3.0-7.0$ for $1 \mathrm{~h}$ at $4^{\circ} \mathrm{C}$. Residual proteolytic activity was then determined under standard assay conditions. The following buffer systems were used: $100 \mathrm{mM}$ glycine- $\mathrm{HCl}$ buffer for $\mathrm{pH} 3.0$ and $3.5,100 \mathrm{mM}$ sodium acetate buffer for $\mathrm{pH} 4.0-6.0$, and $100 \mathrm{mM}$ potassium phosphate buffer for $\mathrm{pH} 6.5$ and 7.0 [22].

2.13.2. Determination of Optimum Temperature and Its Stability. To investigate the effect of temperature, proteolytic activity was tested at different temperatures $(20,25,30$, $35,40,45,50,55,60$, and $65^{\circ} \mathrm{C}$ ) using hemoglobin as a substrate for $5 \mathrm{~min}$ at $\mathrm{pH}$ 5.0. Thermal stability was examined by incubating the enzyme at $30,40,50,60$, and $70^{\circ} \mathrm{C}$ for $60 \mathrm{~min}$. After $60 \mathrm{~min}$, the remaining enzyme activity was determined at optimum $\mathrm{pH}$ and temperature. The nonheated enzyme was considered 100\% [22].

2.14. Data Analysis. Data analyses were performed using SPSS software, version 23 (Inc. Cary NC USA). All experiments were carried out in triplicate. Analysis of variance (ANOVA) and means comparisons were done by SPSS and SigmaPlot, version 12 .

\section{Results}

3.1. Primary Screening of Protease-Producing Fungi. A total of thirty-two (32) fungal isolates were isolated from the soil samples, of which 12 isolates (38\%) showed clear zone hydrolysis on skim milk agar media up on primary screening. The fungal isolates were shown significant clear zone diameter and relative enzyme activity (REA) ranging from $6.7 \mathrm{~mm}$ and $21.3 \mathrm{~mm}$ and between 0.4 and 0.74 , respectively (Table 1). Among the isolates, the highest REA was recorded by the isolates $\mathrm{H} 1 \mathrm{~W} 1(0.8)$ and Z1BL1 (0.74) (Table 1). The spore concentration of all the 12 isolates was determined using the Neubauer chamber and was in the range between $1.2 \times 10^{6}$ and $4.4 \times 10^{8}$ spores/mL (Table 1 ). 
TABle 1: Clear zone diameter of fungal isolates on skim milk agar media.

\begin{tabular}{|c|c|c|c|c|c|}
\hline No. & Isolates & Spore concentration $/ \mathrm{mL}$ & $\mathrm{CD}(\mathrm{mm})$, mean $\pm \mathrm{SEM}$ & $\mathrm{CZD}(\mathrm{mm})$, mean $\pm \mathrm{SEM}$ & REA \\
\hline 1 & $\mathrm{Z}_{1} \mathrm{BL}_{1}$ & $6.54 \times 10^{7}$ & $28.7 \pm 1.5^{\mathrm{b}}$ & $21.3 \pm 1.5^{\mathrm{a}}$ & 0.74 \\
\hline 2 & $\mathrm{H}_{1} \mathrm{BL}_{1}$ & $3.60 \times 10^{6}$ & $14.7 \pm 0.8^{\mathrm{a}}$ & $9.0 \pm 0.6^{\mathrm{cd}}$ & 0.61 \\
\hline 3 & $\mathrm{Z}_{1} \mathrm{BL}_{3}$ & $2.64 \times 10^{8}$ & $19.0 \pm 1.5^{\mathrm{a}}$ & $11.7 \pm 1.2^{\mathrm{c}}$ & 0,61 \\
\hline 4 & $\mathrm{SW}_{2} \mathrm{~W}_{1}$ & $1.81 \times 10^{7}$ & $19.0 \pm 2.0^{\mathrm{a}}$ & $12.3 \pm 0.3^{\mathrm{c}}$ & 0.65 \\
\hline 5 & $\mathrm{SW}_{1} \mathrm{BBr}$ & $8.12 \times 10^{7}$ & $14.3 \pm 1.5^{\mathrm{a}}$ & $6.7 \pm 1.5^{\mathrm{d}}$ & 0.46 \\
\hline 6 & $\mathrm{SW}_{1} \mathrm{YW}_{1}^{+}$ & $1.4 \times 10^{6}$ & $15.7 \pm 1.2^{\mathrm{a}}$ & $8.3 \pm 0.3^{\mathrm{cd}}$ & 0.52 \\
\hline 7 & Code 3 & $2.6 \times 10^{6}$ & $15.7 \pm 0.3^{\mathrm{a}}$ & $10.0 \pm 0.6^{\mathrm{cd}}$ & 0.63 \\
\hline 8 & $\mathrm{Z}_{1} \mathrm{Y}_{2}$ & $1.5 \times 10^{6}$ & $17.3 \pm 0.8^{\mathrm{a}}$ & $7.0 \pm 0.5^{\mathrm{d}}$ & 0.40 \\
\hline 9 & $\mathrm{H}_{1} \mathrm{~W}_{1}$ & $1.2 \times 10^{6}$ & $20.3 \pm 6^{\mathrm{a}}$ & $16.3 \pm 1.2^{\mathrm{b}}$ & 0.80 \\
\hline 10 & $\mathrm{SW}_{1} \mathrm{WY}_{1}$ & $2.2 \times 10^{7}$ & $18.3 \pm 2.4^{\mathrm{a}}$ & $11.7 \pm 0.3^{c}$ & 0.63 \\
\hline 11 & $\mathrm{Z}_{1} \mathrm{BL}_{4}$ & $4.4 \times 10^{8}$ & $16.7 \pm 0.6^{\mathrm{a}}$ & $10.0 \pm 0.6^{\mathrm{cd}}$ & 0.60 \\
\hline 12 & $\mathrm{H}_{1} \mathrm{Gr}_{1}$ & $2.6 \times 10^{6}$ & $15.3 \pm 1.5^{\mathrm{a}}$ & $9.3 \pm 0.3^{\mathrm{cd}}$ & 0.60 \\
\hline
\end{tabular}

Mean is the average of three measurements. SEM: standard error of the mean; REA: relative enzyme activity; CD: colony diameter; CZD: clear zone hydrolysis diameter. Different letters $(a, b, c, d)$ designate significantly different means as determined by the SPSS test $(P<0.05)$.

TABLE 2: Acid protease activity of fungal isolates under SSF.

\begin{tabular}{lccc}
\hline No. & Isolates & Adjusted spore concentration/mL & PA $(\mathrm{U} / \mathrm{mL}), \mathrm{mean} \pm \mathrm{SEM}$ \\
\hline 1 & $\mathrm{Z}_{1} \mathrm{BL}_{4}$ & $3.6 \times 10^{6}$ & $54.9 \pm 1.7^{\mathrm{a}}$ \\
2 & $\mathrm{H}_{1} \mathrm{Gr}_{1}$ & $1.3 \times 10^{6}$ & $38.8 \pm 2.2^{\mathrm{b}}$ \\
3 & $\mathrm{Z}_{1} \mathrm{BL}_{1}$ & $3.2 \times 10^{6}$ & $78.2 \pm 1.5^{\mathrm{a}}$ \\
4 & $\mathrm{Z}_{1} \mathrm{BL}_{3}$ & $3.1 \times 10^{6}$ & $49.2 \pm 1.7^{\mathrm{ab}}$ \\
5 & $\mathrm{SW}_{2} \mathrm{~W}_{1}$ & $2.2 \times 10^{6}$ & $70.1 \pm 2.8^{\mathrm{a}}$ \\
6 & $\mathrm{H}_{1} \mathrm{BL}_{1}$ & $1.8 \times 10^{6}$ & $46.6 \pm 4.0^{\mathrm{b}}$ \\
7 & $\mathrm{Z}_{1} \mathrm{Y}_{2}$ & $1.5 \times 10^{6}$ & $31.7 \pm 1.7^{\mathrm{b}}$ \\
8 & $\mathrm{H}_{1} \mathrm{~W}_{1}$ & $1.2 \times 10^{6}$ & $47.2 \pm 2.8^{\mathrm{ab}}$ \\
9 & $\mathrm{SW}_{1} \mathrm{WY}_{1}$ & $2.0 \times 10^{6}$ & $51.7 \pm 1.7^{\mathrm{ab}}$ \\
\hline
\end{tabular}

Mean is the average of three measurements. SEM: standard error of the mean; PA: protease activity. Different letters $(a, b)$ designate significantly different means as determined by the SPSS test $(P<0.05)$.

\subsection{Secondary Screening of Acid Protease under Solid-State} Fermentation (SSF). All the twelve isolates that showed a relative protease activity $\geq 0.4$ were subjected for further screening in solid-state fermentation. Out of the twelve isolates, 9 isolates showed an acid protease activity under SSF (Table 2). The highest protease activity $(78.2 \mathrm{U} / \mathrm{mL})$ was recorded from the isolate $\mathrm{Z} 1 \mathrm{BL} 1$, whereas the lowest protease activity $(31.7 \mathrm{U} / \mathrm{mL})$ was noticed from the isolate $\mathrm{Z} 1 \mathrm{Y} 2$ under SSF. Hence, the isolate Z1BL1 that showed the highest acid protease activity was selected for further study.

\subsection{Morphological Characterization of Potential Fungal} Isolates. The potential fungal isolate Z1BL1 was identified and categorized under the genus Aspergillus based on microscopic and macroscopic characteristics (Table 3, Figures 2 and 3).

\subsection{Optimization of Media Composition and Growth Conditions for Acid Protease Production by the Isolate Z1BL1}

3.4.1. Effect of Substrate Types for Acid Protease Production. In the present study, two solid substrates (wheat bran and rice bran) moistened by acid/mineral salt solution were used for acid protease production. All the substrates treated by acid and mineral solutions produced significant protease activity. However, the maximum protease activity $(107.4 \mathrm{U} / \mathrm{mL})$ was obtained from the potential isolates (Z1BL1) using wheat bran treated with mineral solution, whereas the least protease activity $(48.5 \mathrm{U} / \mathrm{mL})$ was recorded using rice bran treated with the same mineral solution (Figure 4).

3.4.2. Effect of Incubation Period. The effect of incubation time on the production of acid protease is shown in Table 4. The highest protease activity $(95.2 \mathrm{U} / \mathrm{mL})$ was recorded at $120 \mathrm{~h}$. Further increase in the incubation time reduced the enzyme activity.

3.4.3. Effect of Incubation Temperature. In the present study, the highest protease activity $(106.1 \mathrm{U} / \mathrm{mL})$ was obtained when SSF carried out at a temperature of $30^{\circ} \mathrm{C}$, while the lowest protease activity was achieved at $45^{\circ} \mathrm{C}$ (Figure 5).

3.4.4. Effect of Inoculum Size. The effect of inoculum size on acid protease production by the isolate $\mathrm{Z1BL} 1$ is shown in Figure 6 . The maximum protease activity was obtained at an inoculum size of $1 \mathrm{~mL}\left(3.2 \times 10^{6}\right.$ spores $\left./ \mathrm{mL}\right)$, whereas the lowest activity was recorded at $0.2 \mathrm{~mL}\left(3.2 \times 10^{5}\right.$ spores $\left./ \mathrm{mL}\right)$.

3.4.5. Effect of Media Moisture Content. The effect of moisture content on acid protease production is shown in Figure 7. Accordingly, the maximum enzyme production $(87.4 \mathrm{U} / \mathrm{mL})$ was obtained at $50 \%$ moisture content, whereas 
TABLE 3: Macroscopic characteristics of potential fungal isolates.

\begin{tabular}{|c|c|c|c|c|c|c|c|}
\hline Isolates & Media & Colony growth & Colony texture & $\mathrm{CD}$, mean $\pm \mathrm{SEM}$ & Obverse colony color & Reverse colony color & $\begin{array}{c}\text { Degree of } \\
\text { sporulation }\end{array}$ \\
\hline \multirow{3}{*}{ Z1BL1 } & MEA & Medium & Floccose (cottony) & $28.3 \pm 1.5$ & Black & Dark black & High \\
\hline & CDA & Low & Floccose (cottony) & $21 \pm .5$ & Dark white to gray & Pink & High \\
\hline & PDA & High & Floccose (cottony) & $40.3 \pm 1.2$ & Dark black & Blue-black & High \\
\hline \multirow{3}{*}{$\mathrm{H}_{1} \mathrm{Gr}_{1}$} & MEA & Medium & Rough & $30.7 \pm 2.2$ & Green & White gray & Low \\
\hline & $\mathrm{CDA}$ & Medium & Rough & $29.6 \pm .8$ & White gray & Green & Low \\
\hline & PDA & High & Rough & $43.0 \pm 1$ & Green & White to gray & Medium \\
\hline \multirow{3}{*}{$\mathrm{H}_{1} \mathrm{~W}_{1}$} & MEA & Medium & Floccose (cottony) & $31.3 \pm 2$ & White to brown & Brown & Low \\
\hline & $\mathrm{CDA}$ & Low & Floccose (cottony) & $24.5 \pm .6$ & White to brown & Dark brown & Low \\
\hline & PDA & High & Floccose (cottony) & $38.1 \pm 1.1$ & Yellow & White to yellow & Low \\
\hline \multirow{3}{*}{$\mathrm{SW}_{2} \mathrm{~W}_{1}$} & MEA & High & Floccose (cottony) & $40.4 \pm 3$ & Blue & Brown & Medium \\
\hline & $\mathrm{CDA}$ & Low & Floccose (cottony) & $23.9 \pm 5$ & Brown & White to brown & Medium \\
\hline & PDA & High & Floccose (cottony) & $45.0 \pm .5$ & Brown & Brown with white & High \\
\hline \multirow{3}{*}{$\mathrm{SW}_{1} \mathrm{WY}_{1}$} & MEA & Medium & Rough & $25.5 \pm 2.3$ & White to yellow & White and brown & Medium \\
\hline & $\mathrm{CDA}$ & Medium & Rough & $33.5 \pm 1$ & Yellow & Yellow at white & Medium \\
\hline & PDA & High & Rough & $38.7 \pm 1.2$ & White yellow & Light yellow & High \\
\hline \multirow{3}{*}{$\mathrm{Z}_{1} \mathrm{BL}_{3}$} & MEA & High & Floccose (cottony) & $41.6 \pm 1.4$ & Blue-black & Black & High \\
\hline & $\mathrm{CDA}$ & Medium & Floccose (cottony) & $30.0 \pm 2$ & Black & Dark black & Medium \\
\hline & PDA & High & Floccose (cottony) & $43.0 \pm 1.5$ & Dark black & Blue-black & High \\
\hline \multirow{3}{*}{$\mathrm{Z}_{1} \mathrm{Y}_{2}$} & MEA & Medium & Rough & $29.4 \pm .5$ & Yellow & White & Low \\
\hline & $\mathrm{CDA}$ & Very low & Rough & $13.7 \pm 2.3$ & Yellow & Brown & Low \\
\hline & PDA & Medium & Rough & $31.5 \pm 1.5$ & White & White & Low \\
\hline \multirow{3}{*}{$\mathrm{H}_{1} \mathrm{BL}_{1}$} & MEA & Low & Floccose (cottony) & $20.1 \pm 1.9$ & Blue-black & Dark black & Low \\
\hline & $\mathrm{CDA}$ & High & Floccose (cottony) & $36.6 \pm 1.4$ & Black & Black & Low \\
\hline & PDA & High & Floccose (cottony) & $40.3 \pm .8$ & Dark black & Blue-black & High \\
\hline \multirow{3}{*}{$\mathrm{Z}_{1} \mathrm{BL}_{4}$} & MEA & High & Floccose (cottony) & $36.0 \pm 2$ & Blue-black & Black & Medium \\
\hline & $\mathrm{CDA}$ & Low & Floccose (cottony) & $21.0 \pm 1$ & Black & Dark black & Low \\
\hline & PDA & High & Floccose (cottony) & $36.2 \pm 1.7$ & Black & Blue-black & High \\
\hline
\end{tabular}

CD: colony diameter; MEA: malt extract agar; CDA: Czapek Dox agar; PDA: potato dextrose agar. Colony growth-Very low: $<15 \mathrm{~mm}$; Low: $15-25 \mathrm{~mm}$; Medium: 25-35 mm, High: 35-45 mm; Very high: $>45 \mathrm{~mm}$ [27].

the lowest $(44.7 \mathrm{U} / \mathrm{mL})$ was recorded at a moisture content of $65 \%$.

3.4.6. Effect of Initial Media $p H$. Maximum acid protease production $(92.6 \mathrm{U} / \mathrm{mL})$ by the isolate $\mathrm{Z1BL} 1$ was recorded at initial media $\mathrm{pH} 4.5$. The protease activity was sharply decreased on both sides of $\mathrm{pH} 4.5$ (Figure 8).

3.5. Enzyme Characterization. The crude enzyme was partially purified by acetone and ammonium sulfate precipitation, and the partially purified enzyme was used for characterization. Purification of the enzyme by acetone $\left(\mathrm{NH}_{4}\right)_{2} \mathrm{SO}_{4}$ increased the ratio of MCA/PA while reducing the MCA and PA (Table 5). The highest ratio was recorded from the acetone-precipitated enzyme. Thus, based on the protease activity and ratio (MCA/PA) recorded from the enzymes, the acetone-precipitated enzyme was subjected to further enzyme characterization.

3.5.1. Effect of Temperature on Enzyme Activity and Stability. As shown in Figure 9, the crude enzyme precipitated with chilled acetone showed significant protease activity at a temperature range from $40^{\circ} \mathrm{C}$ to $60^{\circ} \mathrm{C}$. However, the highest activity was recorded at a temperature of $50^{\circ} \mathrm{C}$. The enzyme activity gradually increased with increasing temperature, followed by a steep decrease at temperatures above $50^{\circ} \mathrm{C}$ (Figure 9). The enzyme retained stable (70-79\% of its activity) upon its exposure to a temperature between $40^{\circ} \mathrm{C}$ and $60^{\circ} \mathrm{C}$ (Figure 10) for $1 \mathrm{~h}$.

3.5.2. Effect of $p H$ on Enzyme Activity and Stability. In the present study, the optimum $\mathrm{pH}$ for the activity of acetoneprecipitated enzyme $(97.1 \mathrm{U} / \mathrm{mL})$ was obtained at $\mathrm{pH} 5.0$ (Figure 11).

The $\mathrm{pH}$ stability test for acetone-precipitated enzyme from the isolate $\mathrm{Z1BL} 1$ was stable from $\mathrm{pH} 4-6$ as shown in Figure 12 . The enzyme retained significant activity (83-90\%) upon its exposure at a $\mathrm{pH}$ ranging from 4 to 6 .

\section{Discussion}

In the current study, 12 (38\%) fungal isolates showed a clear zone of hydrolysis on skim milk agar media during primary screening. Skim milk agar plate assay allows qualitative determinations of protease activity, and the hydrolysis zone produced on the agar could be related to the amount of protease produced by the fungus [13, 28, 29]. The fungal isolates produced a clear zone diameter and relative enzyme activity between $6.7 \mathrm{~mm}$ and $21.3 \mathrm{~mm}$ and 0.40 and 0.80 in 48 


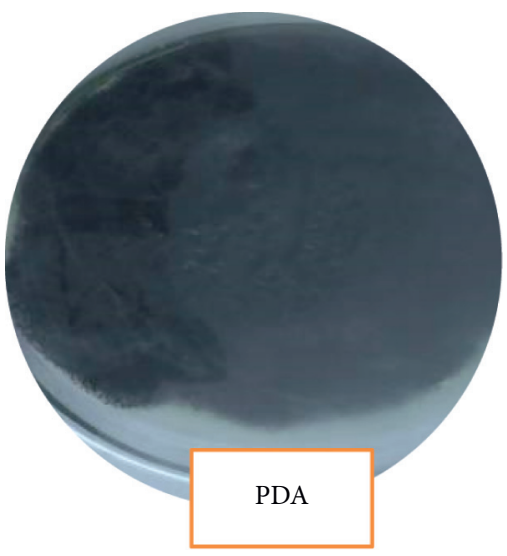

(a)

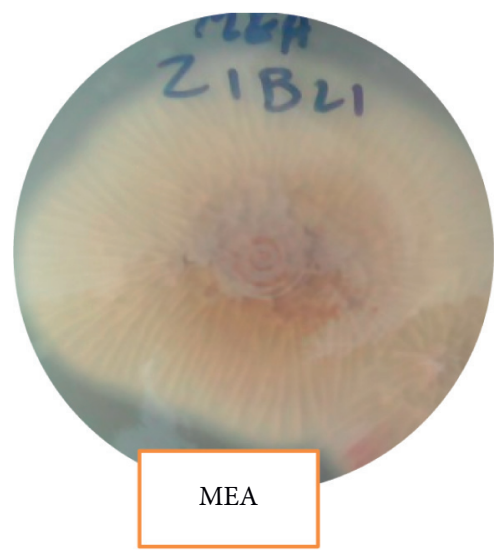

(b)

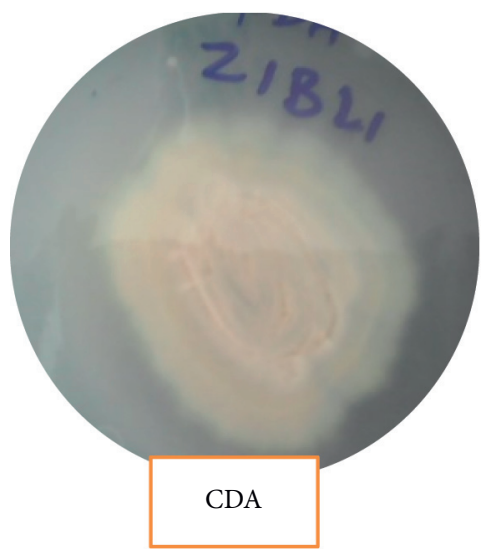

(c)

FIgure 2: Macroscopic features of the isolate Z1BL1.

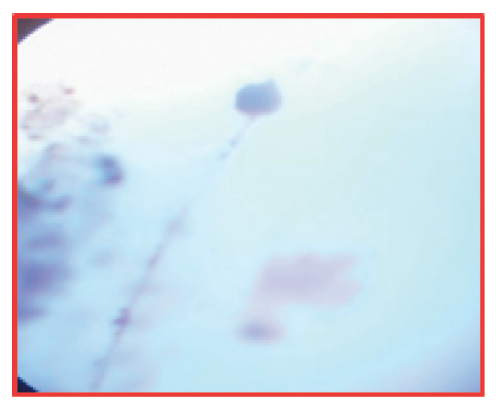

(a)

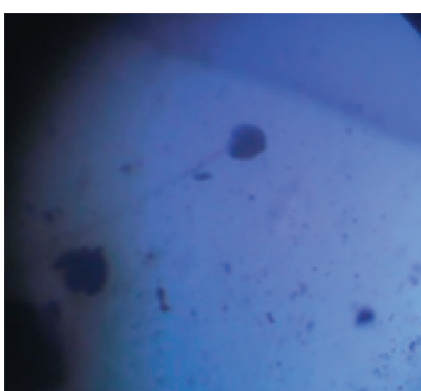

(b)

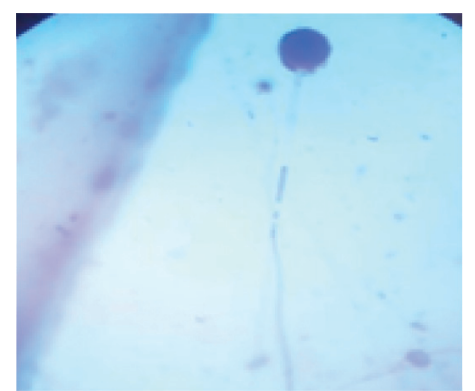

(c)

Figure 3: Microscopic structures of the isolate Z1BL1.

hours, respectively. Similar to the present study, substantial clear zone hydrolysis was reported by Mucor sp. [30] and Aspergillus niger FFB1 [24] on skim milk agar and agar media, respectively, whereas the clear zone diameter $(8 \mathrm{~mm}-19.25 \mathrm{~mm})$ and relative enzyme activity (1.07-2.09) recorded from various filamentous fungi using skim milk agar media up to 48 hours were higher than this study [14]. The variation in clear zone diameter and relative enzyme activity could be attributed to the low media $\mathrm{pH}$ used in this study.

Out of the 12 isolates subjected to secondary screening, 9 isolates were shown significant protease activity (between 31.7 U/mL and 78.2 U/mL) under SSF. This could be due to those filamentous fungi preferred SSF for the production of enzymes [23]. Similar protease activities were also recorded by various Aspergillus spp. under SSF [24, 31-33].

The potential fungal isolate Z1BL1 that exhibited the highest protease activity under SSF was identified and categorized under genus Aspergillus based on macroscopic and microscopic characteristics (Table 3, Figures 2 and 3). In comparison with the present study, filamentous fungal isolates collected from the Petaling Jaya region (Malaysia) were identified and classified into different species under the genus Aspergillus [14]. In another study, Afzal et al. [34] reported the identification of filamentous fungi into the genus Aspergillus based on the morphological features.
Moisture content is one of the significant factors in enzyme production in solid-state fermentation [35] since microbial growth and product formation occur at or near the surface particle with an optimized water level that controls the water activity $\left(a_{W}\right)$ [15]. In this study, the highest protease activity was observed from the crude enzyme produced at 50\% moisture content (Figure 7). Similar to the present study, the maximum milk-clotting enzyme from Aspergillus spp. was produced at $55 \%$ moisture content under SSF [7, 31]. The high moisture content of the fermentation media decreased the porosity and oxygen transfer that may affect the enzyme production [36].

The optimum initial media $\mathrm{pH}$ for acid protease production by the isolate $\mathrm{Z1BL} 1$ was found at $\mathrm{pH} 4.5$ (Figure 8). Further increasing the media $\mathrm{pH}$ significantly reduced enzyme production, and this implies that the fungus (Z1BL1) prefer an acidic media $\mathrm{pH}$ for inducing acid protease. A similar observation was reported by Yegin et al. [37] on the production of aspartic protease from Mucor mucedo. In other studies, maximum acid protease activity from $R h i$ zopus oligosporus HIS13 [38] and Aspergillus species [33] under SSF was also obtained at initial media pH 5. Generally, changes in $\mathrm{pH}$ during the SSF procedure were rarely controlled, except the initial $\mathrm{pH}$ of the substrate that is adjusted before inoculation [24]. 


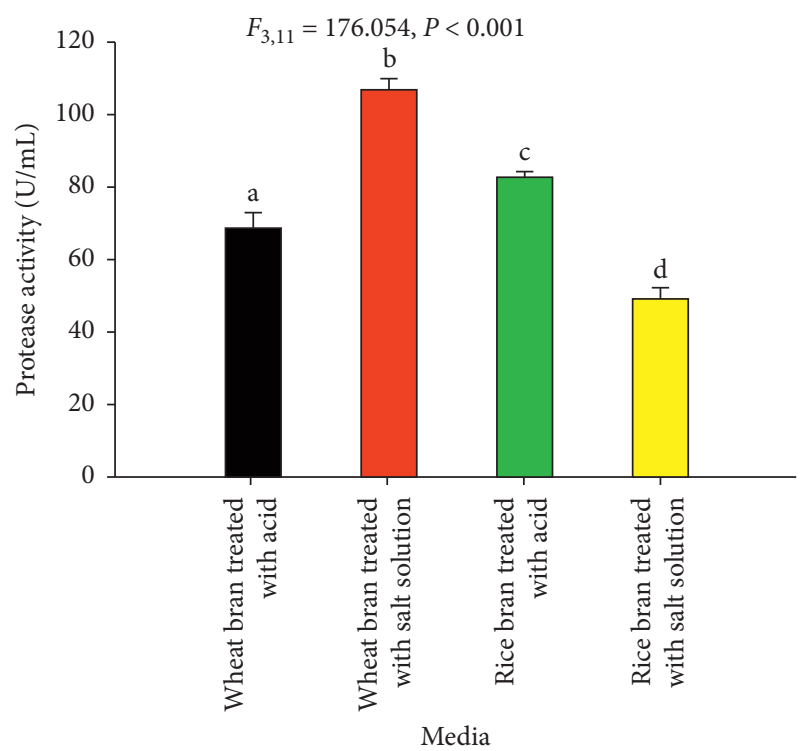

FIgURE 4: Screening of two agro-industrial residues for acid protease production from the filamentous fungal isolate Z1BL1. Mean is the average of three measurements. Different letters (a, b, c, d) designate significantly different means as determined by the SPSS test $(P<0.001)$; temperature $30^{\circ} \mathrm{C}$; initial media $\mathrm{pH} 4.5$.

TABLE 4: Effect of incubation period on acid protease production by the isolate Z1LB1.

\begin{tabular}{lcc}
\hline No. & Incubation period (in hour) & PA $(\mathrm{U} / \mathrm{mL})$ mean \pm SEM \\
\hline 1 & 24 & - \\
2 & 48 & $36.8 \pm 5^{\mathrm{a}}$ \\
3 & 72 & $56.3 \pm 7^{\mathrm{b}}$ \\
4 & 96 & $88.0 \pm 5.2^{\mathrm{c}}$ \\
5 & 120 & $95.2 \pm 7^{\mathrm{c}}$ \\
6 & 144 & $71.8 \pm 4.9^{\mathrm{bc}}$ \\
\hline
\end{tabular}

PA: protease activity; SEM: standard error of the mean. Mean is the average of three measurements. Different letters $(\mathrm{a}, \mathrm{b}, \mathrm{c})$ designate significantly different means as determined by the SPSS test $(P<0.001)$; temp. $30^{\circ} \mathrm{C}$; initial media $\mathrm{pH} 4.5$.

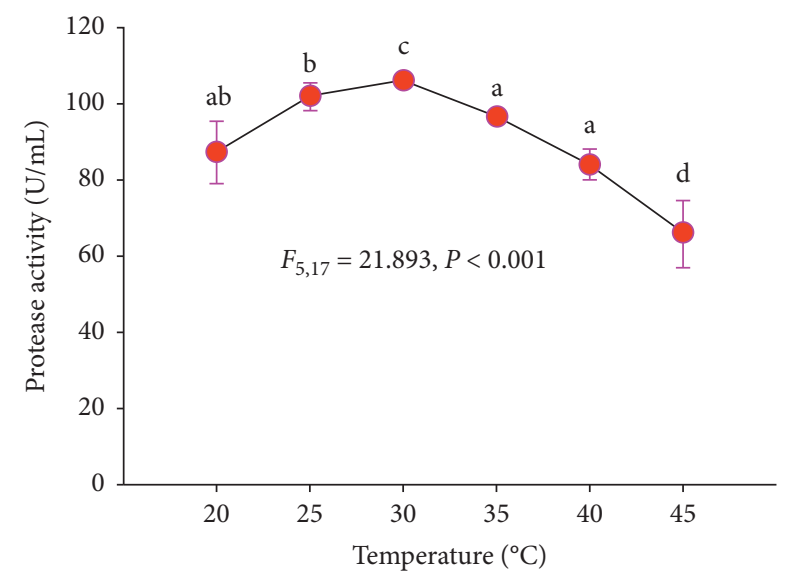

FIGURE 5: Effect of incubation temperature on acid protease production from the filamentous fungal isolate Z1BL1 in SSF. Different letters ( $a, b, c, d)$ designate significantly different means as determined by the SPSS test $(P<0.001)$; temperature $30^{\circ} \mathrm{C}$; initial media $\mathrm{pH} 4.5$.

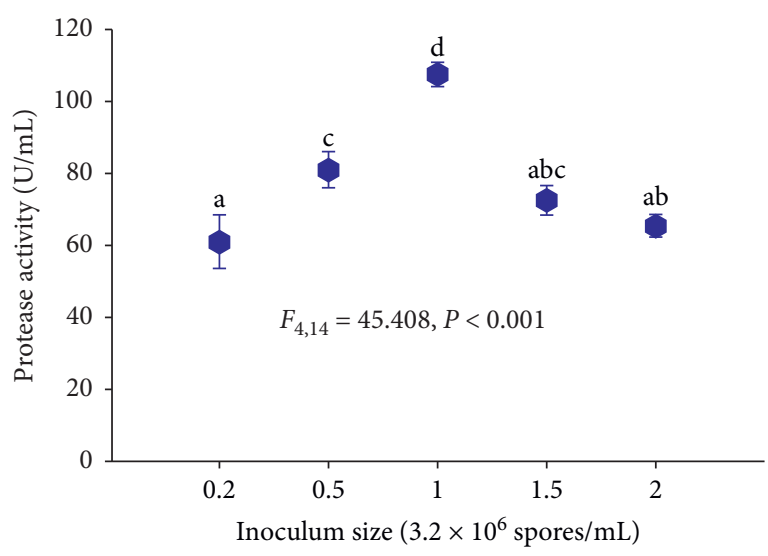

FIGURE 6: Effect of inoculum size on the production acid protease by the isolate Z1BL1. Different letters ( $a, b, c, d)$ designate significantly different means as determined by the SPSS test $(P<0.001)$; initial media $\mathrm{pH} 4.5$; temperature $30^{\circ} \mathrm{C}$.

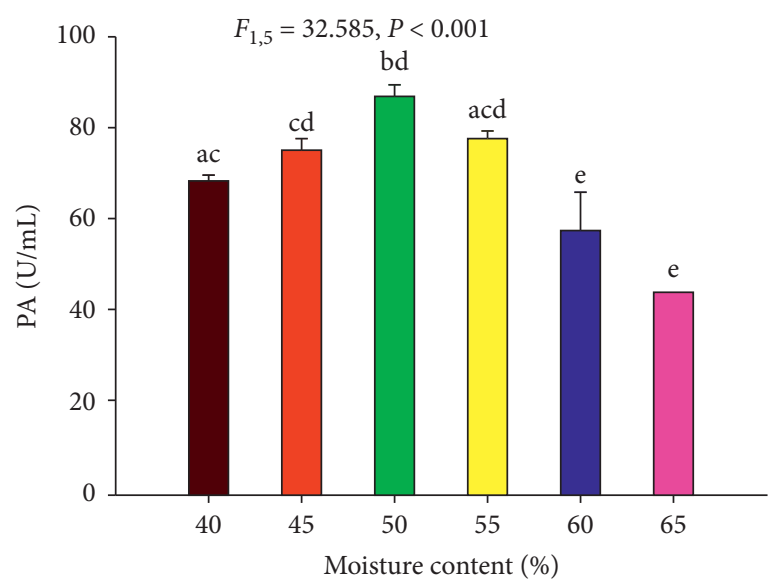

FIGURE 7: Effect of moisture content on acid protease production by the filamentous fungal isolate Z1BL1 in SSF. PA: protease activity. Different letters $(\mathrm{a}, \mathrm{b}, \mathrm{c}, \mathrm{d}, \mathrm{e})$ designate significantly different means as determined by the SPSS test $(P<0.001)$; wheat bran moistened with the salt solution; initial media $\mathrm{pH} 5$; temperature $30^{\circ} \mathrm{C}$.

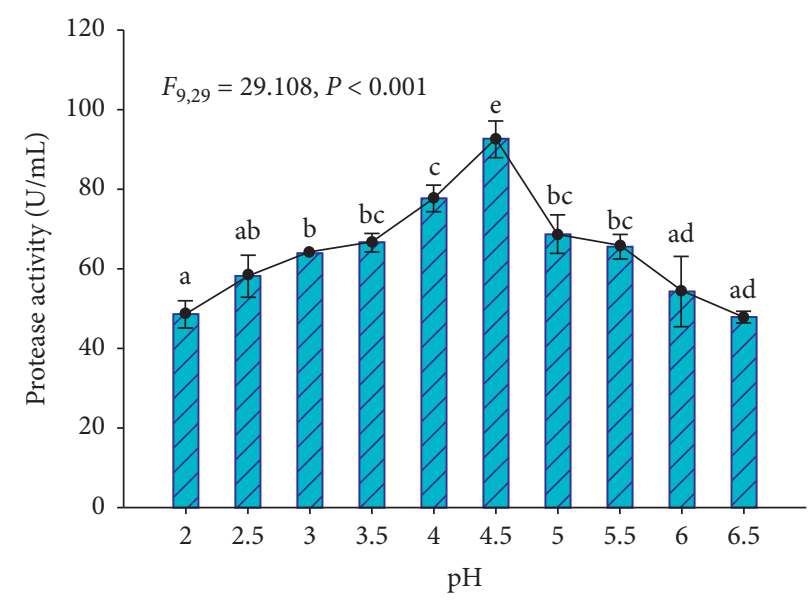

FIGURE 8: Effect of initial media $\mathrm{pH}$ on the production of acid protease from filamentous fungi Z1BL1 in SSF. Different letters (a, b, c, d, e) designate significantly different means as determined by SPSS test $(P<0.001)$; wheat bran moistened with a salt solution; temperature $30^{\circ} \mathrm{C}$. 
TABLE 5: Protease activity of the crude enzyme and partially purified enzyme from the isolate Z1BL1.

\begin{tabular}{lccc}
\hline Sample & MCA $(\mathrm{U} / \mathrm{mL})$, mean \pm SEM & PA $(\mathrm{U} / \mathrm{mL})$, mean \pm SEM & Ratio MCA/PA \\
\hline Crude enzyme & $99.2 \pm 1.7$ & $107.6 \pm 1$ & 0.92 \\
Acetone-precipitated enzyme & $75.7 \pm 1.0$ & $50.4 \pm 1.1$ & 1.50 \\
$\left(\mathrm{NH}_{4}\right)_{2} \mathrm{SO}_{4}$ precipitated enzyme & $64.7 \pm 2.3$ & $48.2 \pm 4.0$ & \\
\hline
\end{tabular}

MCA: milk clotting activity; PA: protease activity; ratio: the ratio of MCA/PA; SEM: standard error of the mean; mean: an average of three measurements.

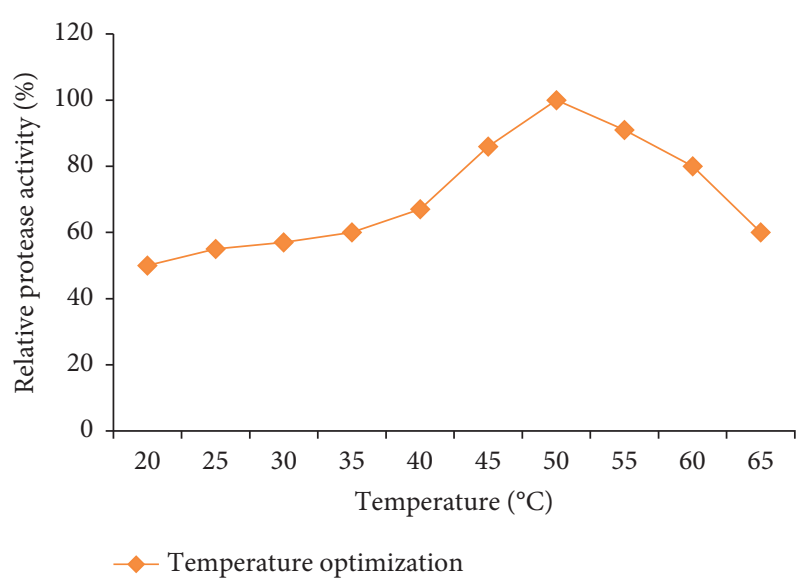

FIGURE 9: Temperature optimization of PA for acetone-precipitated enzyme from the isolate Z1BL1.

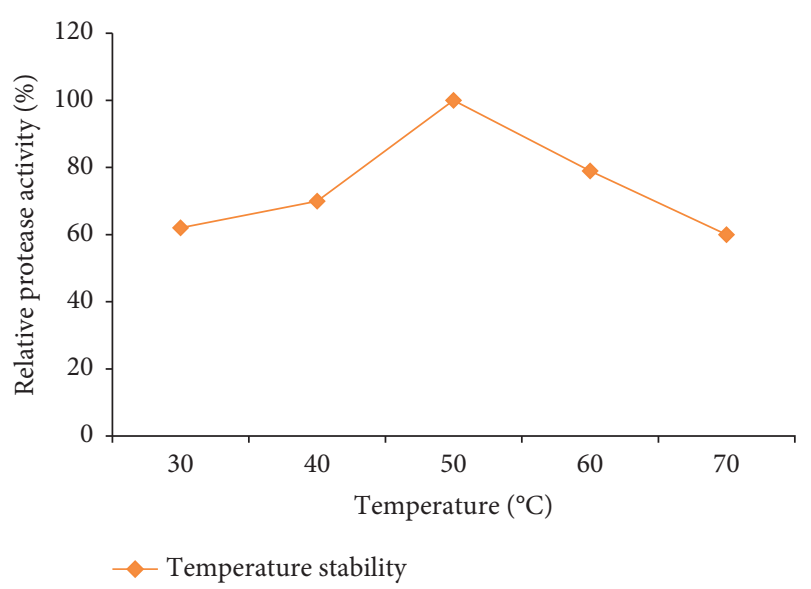

FIgURE 10: Temperature stability of PA for acetone-precipitated enzyme from the isolate Z1BL1.

The protease activity was measured for $144 \mathrm{~h}$ within $24 \mathrm{~h}$ interval, and the maximum yield $(95.2 \mathrm{U} / \mathrm{mL})$ was noticed at $120 \mathrm{~h}$ of the incubation period (Table 4). Further incubation significantly reduced the enzyme production. The reduction in enzyme yield after the optimum incubation period was probably due to the depletion of nutrients available for microbial growth [15]. The maximum enzyme activity recorded from M. circinelloides, A. oryzae MTCC 5341, and Aspergillus spp. on 120-h fermentation time under SSF was comparable with the present study $[15,39,40]$.

In this study, acid protease production carried out at $30^{\circ} \mathrm{C}$ was the most suitable incubation temperature for the

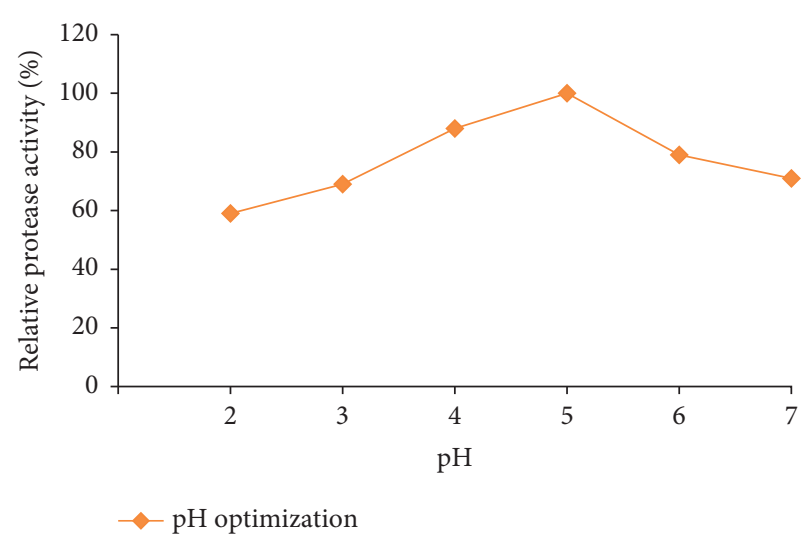

FIGURE 11: pH optimization of PA for acetone-precipitated enzyme from the isolate Z1BL1.

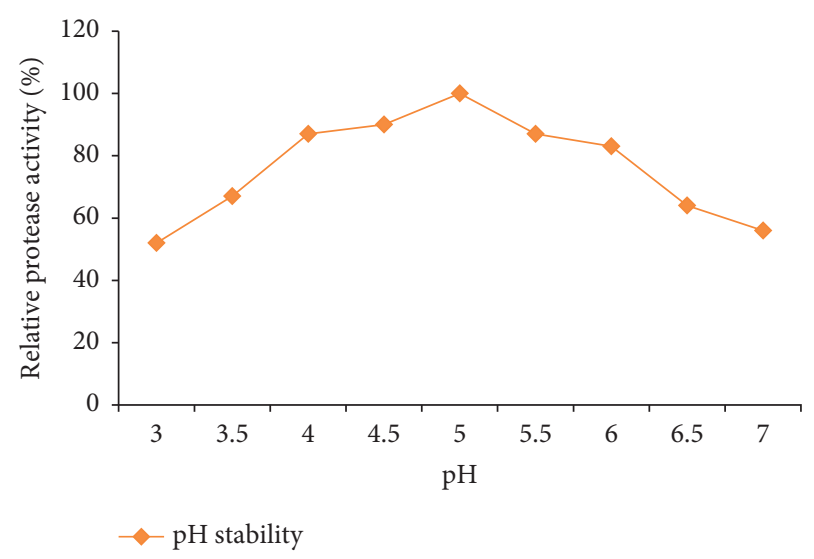

FIGURE 12: pH stability test for acetone-precipitated enzyme from the isolate Z1BL1.

isolate Z1BL1 with protease activity of $106.1 \mathrm{U} / \mathrm{mL}$ (Figure 5), and any fluctuations from this optimum temperature significantly reduced the enzyme activity. The production of the enzyme is directly related to the biomass of the fungi, which implies optimum growth temperature for the isolate $\mathrm{Z}_{1} \mathrm{BL}_{1}$ was at $30^{\circ} \mathrm{C}$. Similar to the current study, optimum acid protease production by Aspergillus spp. was obtained at $30^{\circ} \mathrm{C}[24,32,33,39]$. In another study, Shieh et al. [41] also reported maximum milk-clotting proteases production by Amylomyces rouxii, Mucor pusillus, and Mucor $\mathrm{J} 20$ at $30^{\circ} \mathrm{C}$. A maximum acid protease activity was also recorded from A. oryzae $\mathrm{HG} 76$ at $30^{\circ} \mathrm{C}$ and showed a significant decrease when the temperature goes higher or lower [42].

The selection of the best substrate for enzyme production in SSF process is governed by several factors, 
mainly related to the cost and availability of the substrate material, and thus may involve screening of agricultural waste products [43]. In the present study, the suitability of two substrates (wheat bran and rice bran) moistened with acid/mineral solution was verified for protease production in SSF. The highest enzyme activity was obtained from wheat bran moistened with mineral solution. The variation in protease activity between the solid substrates could be due to differences in the biochemical composition and in particle size, which is partly related to porosity even though the particle size of each substrate was not determined [44]. In other studies, wheat bran is considered the best substrate for the production of acid protease from A. oryzae MTCC 5341 [39], other Aspergillus species [24, 42], and Mucor species [45].

The size of the inoculum is an important biological factor that determines biomass production during fermentation. A highly concentrated inoculum may produce excessive biomass leading to the rapid depletion of nutrients needed for the rapid growth of the culture and production of metabolites, while a lower inoculum density may give insufficient biomass inducing low yields of products [24, 46, 47]. Thus, determining an appropriate inoculum size in SSF is vital for optimum biomass growth and hence maximum enzyme production. In the present study, the highest protease activity $(107.4 \mathrm{U} / \mathrm{mL})$ of the crude enzyme produced from Z1BL1 was obtained using an inoculum size of $1 \mathrm{~mL}$ $\left(3.2 \times 10^{6}\right.$ spores $/ \mathrm{mL}$ ) (Figure 6). Differently, maximum protease production from $A$. oryzae NRRL 1808 [46] and Mucor circinelloides [15] was reported at $8 \times 10^{8}$ spores $/ \mathrm{mL}$ and $10^{8}$ spores $/ \mathrm{mL}$, respectively.

The extra addition of inoculum size to $6.4 \times 10^{6}$ spores/ $\mathrm{mL}$ substantially decreased acid protease activity. The decrease in enzyme activity that has been observed with higher inoculum size could be due to the shortage of the nutrients available for the larger biomass and faster growth of the culture. Hence, a balance between the proliferating biomass and available material is vital for maximum enzyme production [46].

Characterization of protease is an important practice to determine the optimum temperature and $\mathrm{pH}$ of the enzyme for its application. In this study, the crude enzyme precipitated using acetone was used for characterization. The partially purified enzyme showed maximum activity at temperature $50^{\circ} \mathrm{C}$ and stability at a temperature between $40^{\circ} \mathrm{C}$ and $60^{\circ} \mathrm{C}$. The thermostability of the enzyme showed in this study corresponds with the potential applications of the enzyme in food industries such as bakery and brewery [4, 33], and the highest activity of acid protease from Aspergillus oryzae MTCC 5341 at $55^{\circ} \mathrm{C}$ and its stability between 40 and $57^{\circ} \mathrm{C}$ were also reported [30]. The acid protease was most active at $\mathrm{pH} 5.0$, and the protease activity decreased significantly below and above this value. The enzyme was active from $\mathrm{pH} 4$ up to 6 as shown in Figure 12. This suggests that the enzyme is active at acidic $\mathrm{pH}$ and appropriate for the food industry and beverage industry [5]. Similarly, Oseni [48] reported the highest activity of acid protease from $A s$ pergillus spp. at $\mathrm{pH}$ 5. Optimum $\mathrm{pH}$ values between 3.0 and 5.5 have been reported for protease activities of other fungi, such as Penicillium camemberti ( $\mathrm{pH} 3.5$ ) [49], and Rhizopus oryzae ( $\mathrm{pH} 5.5$ ) [50]. The optimum pH of NRRL 1785 protease, which exhibited an optimum level at $\mathrm{pH}$ 4.0, was comparable with the current study [51]. Thus, the stability of the enzyme in the present study corresponds with the $\mathrm{pH}$ used for food processing for the food and beverage industries [33].

\section{Conclusions}

Filamentous fungi isolated from dairy and grape farm soil have the potential to produce acid protease. From primary and secondary screening, isolate Z1BL1 was selected as a potential fungus for acid protease production under SSF. The potential isolate was successfully identified and categorized under genus Aspergillus using macroscopic and microscopic features. Optimization of media composition and growth conditions of the isolate Z1BL1 slightly increased the acid protease production. Characterization of the partially purified enzyme confirms that the enzyme works best at $\mathrm{pH} 5$ and $50^{\circ} \mathrm{C}$. Thus, based on the above findings, isolate $\mathrm{Z} 1 \mathrm{BL} 1$ could be a potential candidate for production of acid protease applicable in the food industry.

\section{Data Availability}

The experimental data used to support the findings of this study are included within the article.

\section{Consent}

Consent was provided by all researchers participated in the study and included in the publication.

\section{Conflicts of Interest}

The authors declare that there are no conflicts of interest.

\section{Authors' Contributions}

Abdilabar Usman contributed to acquisition and analysis; interpreted the data; and drafted the work. Jermen Mamo contributed to conception, acquisition, and analysis; interpreted the data; drafted the work; and analyzed and substantively revised the work. Said Mohammed contributed to the analysis; interpreted data; and revised the draft work. All authors agreed to publish this research article.

\section{Acknowledgments}

The authors acknowledge the Department of Biology, College of Natural and Computational Science, for funding, facilitation of laboratory space, and provision of other facilities. Besides this, the authors acknowledge the Research Square for the presentation of the manuscript "Production, Optimization, and Characterization of an Acid Protease from Filamentous Fungi by Solid-State Fermentation" as a preprint. This work was supported by the Department of 
Biology, College of Natural and Computational Science, Debre Berhan University.

\section{References}

[1] N.-W. Hsiao, Y. Chen, Y.-C. Kuan et al., "Purification and characterization of an aspartic protease from the Rhizopus oryzae protease extract, Peptidase R," Electronic Journal of Biotechnology, vol. 17, no. 2, pp. 89-94, 2014.

[2] P. M. Souza, G. Werneck, B. Aliakbarian et al., "Production, purification and characterization of an aspartic protease from Aspergillus foetidus," Food and Chemical Toxicology, vol. 109, pp. 1103-1110, 2017.

[3] N. Hassan, M. Rafiq, M. Rehman, W. Sajjad, F. Hasan, and S. Abdullah, "Fungi in acidic fire: a potential source of industrially important enzymes," Fungal Biology Reviews, vol. 33, no. 1, pp. 58-71, 2018.

[4] K. Vishwanatha, A. Appurao, and S. Singh, "Characterisation of acid protease expressed from Aspergillus oryzae MTCC 5341," Food Chemistry, vol. 114, no. 2, pp. 402-407, 2009.

[5] J. Mamo and F. Assefa, "The role of microbial aspartic protease enzyme in food and beverage industries," Journal of Food Quality, vol. 2018, Article ID 7957269, 15 pages, 2018.

[6] R. Gupta, Q. Beg, S. Khan, and B. Chauhan, "An overview on fermentation, downstream processing and properties of microbial alkaline proteases," Applied microbiology and biotechnology, vol. 60, pp. 381-395, 2002.

[7] J. Mamo, M. Kangwa, H. M. Fernandez-Lahore, and F. Assefa, "Optimization of media composition and growth conditions for production of milk-clotting protease (MCP) from Aspergillus oryzae DRDFS13 under solid-state fermentation," Brazilian Journal of Microbiology, vol. 51, no. 2, 2020.

[8] Y. Abdissa, T. Tekalign, and L. Pant, "Growth, bulb yield, and quality of onion (Allium cepa L.) as influenced by nitrogen and phosphorus fertilization on vertisol I. growth attributes, biomass production, and bulb yield," African Journal of Agricultural Research, vol. 6, pp. 3252-3258, 2011.

[9] H. Bedu, K. Tafess, B. Shelima, D. Woldeyohannes, B. Amare, and A. Kassu, "Bovine cysticercosis in cattle slaughtered at Zeway municipal abattoir: prevalence and its public health importance," Journal of Veterinary Science and Technology, vol. 2, pp. 2157-7579, 2011.

[10] T. Shamebo and B. Petros, "Trend analysis of malaria prevalence in Halaba special district," Southern Ethiopia, vol. 12, no. 190, pp. 2-6, 2019.

[11] S. L. Li, S. L. Feng, Z. T. Li et al., "Isolation, identification and characterization of oleaginous fungi from the soil of Qinghai Plateau that utilize D-xylose," African Journal of Microbiology Research, vol. 5, pp. 2075-2081, 2011.

[12] S. Oyeleke, E. C. Egwim, and S. Auta, "Screening of Aspergillus flavus and Aspergillus fumigatus strains for extracellular protease enzyme production," Journal of Microbiology and Antimicrobial, vol. 2, pp. 83-87, 2010.

[13] S. Saran, J. Isar, and R. K. Saxena, "A modified method for the detection of microbial proteases on agar plates using tannic acid," Journal of Biochemical and Biophysical Methods, vol. 70, no. 4, pp. 697-699, 2007.

[14] A. M. A. Maitig, M. A. Alhoot, and K. Tiwari, "Isolation and screening of extracellular protease enzyme from fungal isolates of soil," Journal of Pure and Applied Microbiology, vol. 12, pp. 2059-2068, 2018.
[15] R. Sathya, B. V. Pradeep, J. Angayarkanni, and M. Palaniswamy, "Production of milk clotting protease by a local isolate of Mucor circinelloides under SSF using agroindustrial wastes," Biotechnology and Bioprocess Engineering, vol. 14, no. 6, pp. 788-794, 2009.

[16] H. M. Fernández-Lahore, E. R. Fraile, and O. Cascone, "Acid protease recovery from a solid-state fermentation system," Journal of Biotechnology, vol. 62, no. 2, pp. 83-93, 1998.

[17] G. G. d. Silveira, G. M. d. Oliveira, E. J. Ribeiro, R. Monti, and J. Contiero, "Microbial rennet produced by Mucor miehei in solid-state and submerged fermentation," Brazilian Archives of Biology and Technology, vol. 48, no. 6, pp. 931-937, 2005.

[18] A. A. Kembhavi, A. Kulkarni, and A. Pant, "Salt-tolerant and thermostable alkaline protease fromBacillus subtilis NCIM No. 64," Applied Biochemistry and Biotechnology, vol. 38, no. 1-2, pp. 83-92, 1993.

[19] K. Arima, J. Yu, and S. Iwaski, "Milk clotting enzyme from Mucor pusillus," Edited by Perlman, Ed., Academic Press, New York, NY, USA, 1970.

[20] N. A. Zulkifli and L. Zakaria, "Morphological and molecular diversity of Aspergillus from corn grain used as livestock feed," HAYATI Journal of Biosciences, vol. 24, no. 1, pp. 26-34, 2017.

[21] D. H. Ellis, S. Davis, H. Alexiou, R. Handke, and R. Bartley, Descriptions of Medical Fungi, University of Adelaide Adelaide, Adelaide, Australia, 2007.

[22] R. Siala, F. Frikha, S. Mhamdi, M. Nasri, and A. Sellami Kamoun, "Optimization of acid protease production by $A s$ pergillus niger I1 on shrimp peptone using statistical experimental design," The Scientific World Journal, vol. 2012, Article ID 564932, 11 pages, 2012.

[23] K. S. Vishwanatha, A. G. A. Rao, and S. A. Singh, "Acid protease production by solid-state fermentation using Aspergillus oryzae MTCC 5341: optimization of process parameters," Journal of Industrial Microbiology \& Biotechnology, vol. 37, no. 2, pp. 129-138, 2010.

[24] S. Bensmail, A. Mechakra, and F. Fazouane-Naimi, "Optimization of milk-clotting protease production by a local isolate of Aspergillus niger ffb1 in solid-state fermentation," Journal of Microbiology, Biotechnology and Food Sciences, vol. 04, no. 05, pp. 467-472, 2015.

[25] S. Palpperumal, S. Sankaralingam, D. Kathiresan, B. Harinathan, T. Shankar, and D. Prabhu, "Partial purification and characterization of a haloalkaline protease from Pseudomonas aeruginosa," British Microbiology Research Journal, vol. 15, no. 3, pp. 1-7, 2016.

[26] A. Nouani, F. Moulti-Mati, S. Belbraouet, and M. Bellal, "Purification and characterization of a milk-clotting protease from Mucor pusillus: method comparison," African Journal of Biotechnology, vol. 10, pp. 1655-1665, 2011.

[27] S. Perkhofer, B. E. Kehrel, M. P. Dierich et al., "Human platelets attenuate Aspergillus species via granule-dependent mechanisms," Journal of Infectious Diseases, vol. 198, pp. 1243-1246, 2008.

[28] J. Gnanadoss, R. Robert, and R. Jebapriya, "Production of protease from Aspergillus niger and Mucor mucedo under submerged and solid state fermentation," International Journal of Current Research, vol. 3, pp. 75-78, 2011.

[29] R. Suganthi, J. Benazir, R. Santhi et al., "Amylase production by Aspergillus niger under solid state fermentation using agroindustrial wastes," IJEST, vol. 3, pp. 1756-1763, 2011.

[30] I. A. A. A. Ayana, A. E. Ibrahim, and W. I. A. Saber, "Statistical optimization of milk clotting enzyme biosynthesis by Mucor mucedo Kp736529 and its further application in cheese 
production," International Journal of Dairy Science, vol. 10, no. 2, pp. 61-76, 2015.

[31] J. Chutmanop, S. Chuichulcherm, Y. Chisti, and P. Srinophakun, "Protease production by Aspergillus oryzae in solid-state fermentation using agroindustrial substrates," Journal of Chemical Technology \& Biotechnology, vol. 83, no. 7, pp. 1012-1018, 2008.

[32] H. Mukhtar, "Production of acid protease by Aspergillus niger using solid state fermentation," Pakistan Journal of Zoology, vol. 41, 2009.

[33] S. Shivakumar, "Production and characterization of an acid protease from a local Aspergillus sp. by Solid substrate fermentation," Archives of Applied Science Research, vol. 4, pp. 188-199, 2012.

[34] H. Afzal, S. Shazad, S. Qamar, and S. Nisa, "Morphological identification of Aspergillus spp. from the soil of Larkana district (Sindh, Pakistan)," Asian Journal of Agriculture, vol. 1, p. e17, 2013.

[35] M. Hashemi, S. A. Shojaosadati, S. H. Razavi, S. M. Mousavi, K. Khajeh, and M. Safari, "The efficiency of temperature-shift strategy to improve the production of $\alpha$-amylase by Bacillus sp. in a solid-state fermentation system," Food and Bioprocess Technology, vol. 5, no. 3, pp. 1093-1099, 2012.

[36] C. R. Soccol, E. S. F. d. Costa, L. A. J. Letti, S. G. Karp, A. L. Woiciechowski, and L. P. d. S. Vandenberghe, "Recent developments and innovations in solid state fermentation," Biotechnology Research and Innovation, vol. 1, no. 1, pp. 5271, 2017.

[37] S. Yegin, M. Fernandez-Lahore, M. Ullrich, and M. Polidori, Cloning and Expression of the Aspartic Proteinase from Mucor Mucedo: Structural Characterization and Technological Properties in Comparison with the Native Enzyme, Jacobs University Bremen, Bremen, Germany, 2011.

[38] H. Ikramul, M. Hamid, D. Sunila, A. Sikander, and M. A. Qadeer, "Production of proteases by a locally isolated mould culture under lab conditions," Biotechnology, vol. 2, pp. 30-36, 2003.

[39] K. S. Vishwanatha, A. G. Appu Rao, and S. A. Singh, "Production and characterization of a milk-clotting enzyme from Aspergillus oryzae MTCC 5341," Applied Microbiology and Biotechnology, vol. 85, no. 6, pp. 1849-1859, 2010.

[40] S. Radha, A. Sridevi, R. Himakiranbabu, V. Nithya, N. Prasad, and G. Narasimha, "Medium optimization for acid protease production from Aspergillus sp. under solid state fermentation and mathematical modelling of protease activity," Journal of Microbiology and Biotechnology Research, vol. 2, pp. 6-16, 2012.

[41] C.-J. Shieh, L.-A. Phan Thi, and I.-L. Shih, "Milk-clotting enzymes produced by culture of Bacillus subtilis natto," Biochemical Engineering Journal, vol. 43, no. 1, pp. 85-91, 2009.

[42] C. Li, D. Xu, M. Zhao, L. Sun, and Y. Wang, "Production optimization, purification, and characterization of a novel acid protease from a fusant by Aspergillus oryzae and Aspergillus niger," European Food Research and Technology, vol. 238, no. 6, pp. 905-917, 2014.

[43] M. S. Foda, M. E. Moharam, A. Ramadan, and M. A. ELBendary, "Overproduction of milk-clotting enzyme from Rhizomucor miehei through adjustment of growth under solid state fermentation conditions," AJBAS, vol. 6, pp. 579-589, 2012.

[44] R. J. S. De Castro and H. H. Sato, "Production and biochemical characterization of protease from Aspergillus oryzae: an evaluation of the physical-chemical parameters using agroindustrial wastes as supports," Biocatalysis and Agricultural Biotechnology, vol. 3, no. 3, pp. 20-25, 2014.

[45] P. Patil, A. Kulkarni, and P. Kininge, "Production of milkclotting enzyme from Aspergillus oryzae under solid-state fermentation using mixture of wheat bran and rice bran," IJSRP, vol. 2, p. 1, 2012.

[46] C. Sandhya, A. Sumantha, G. Szakacs, and A. Pandey, "Comparative evaluation of neutral protease production by Aspergillus oryzae in submerged and solid-state fermentation," Process Biochemistry, vol. 40, no. 8, pp. 2689-2694, 2005.

[47] A. K. Sharma, V. Sharma, J. Saxena, B. Yadav, A. Alam, and A. Prakash, "Isolation and screening of extracellular protease enzyme from bacterial and fungal isolates of soil," International Journal of Scientific Research in Environmental Sciences, vol. 3, no. 9, pp. 334-340, 2015.

[48] O. Oseni, "Production of microbial protease from selected soil fungal isolates," $N J B$, vol. 23, 2011.

[49] J. Chrzanowska, M. Kolaczkowska, M. Dryjański, D. Stachowiak, and A. Polanowski, "Aspartic proteinase from Penicillium camemberti: purification, properties, and substrate specificity," Enzyme and Microbial Technology, vol. 17, no. 8, pp. 719-724, 1995.

[50] D. M. Kumar, V. Premavathi, N. Govindarajan, M. Balakumaran, and P. Kalaichelvan, "Production and purification of alkaline protease from Bacillus sp. MPTK 712 isolated from dairy sludge," Glo Vet, vol. 8, pp. 433-439, 2012.

[51] F. Olajuyigbe, J. Ajele, and T. Olawoye, "Some physicochemical properties of acid protease produced during growth of Aspergillus niger (NRRL 1785)," Global Journal of Pure and Applied Sciences, vol. 9, pp. 523-528, 2003. 